\title{
THE MOTIVATION OF PRIMARY WORK
}

\author{
HILDA M. HOLMES \\ State Normal School, San Francisco, California
}

One hears a great deal these days about motivation. Like the many doctrines, theories, and methods which have preceded it, it is in its turn being hailed as a panacea for all our educational evils, disciplinary and otherwise. Is Johnny a discipline case? Is he hopelessly retarded? He is evidently not motivated. "Motivate the child." The phrase is on every educator's tongue, but what does it mean? How is it achieved?

No creative work needs motivating. The artist needs no inducement to paint, nor the composer to produce. Admittedly these types of work are creative, but how can such unemotional facts as acquiring sight words in reading, or the forty-five combinations in arithmetic, be creative work?

Every child who has not previously had reading or arithmetic recreates them for himself. If, instead of spending so much energy in trying to "teach" these subjects to the child, and so much misspent ingenuity in inventing devices for getting over difficultiesoften raised by ourselves-we allowed the child freedom to attack these subjects, it would be found that he would learn by means of his own inevitable development, due to the action of the creative impulse within him. In that sense the work would be creative instead of merely a mechanical drive, and the child would be motivated.

An attempt to motivate primary work has been made recently at the San Francisco State Normal School in four low primary classes, two of which were receiving classes, and two, a mixture of high first and low second grades. We resolved not to use any devices or sugar-coating to make any part of the course of study superficially palatable, claiming that with due recognition of the child's tendency towards activity, if the work were suited to his stage of development, he would react to it.

We then set about the task of motivation. First, we decided that the child must have absolute free choice of work. He could 
not be expected to work on a program with small doses of each subject in turn and work with full interest and energy on arithmetic at a time when possibly his real desire was to read. But did this mean license? Did it mean that the child was to be able to do what he wanted to do, and nothing else? How could he choose his various activities? Was there a possible basis for a sensible decision as to what to do? Could a child in the receiving class, or in any of the low primary classes make such a decision? These were some of the questions which confronted us.

With these questions in view, the material for teaching the usual primary subjects was made as objective and as self-instructive as possible. At the outset the teacher gave a number of presentation lessons on a very free elastic program. The length of the lessons was determined by the length of time the children's interest lasted, the teacher's only care being to make clear to the children the use of the material and to try to present all the subjects in one morning. Soon the children were familiar with the use of this material, reading-slips, counting-cards, etc. Then the teacher took a sight word lesson to the point of exhaustion. She had previously placed phonics material and number-writing materials on every child's desk, and as each child's interest waned, she told him he might choose to do either phonics or number-writing, thus giving him an easy choice of either of two things. The children were given the opportunity to make this simple choice for a few days. Then material for the different subjects was placed on their desks and they were given full charge of their own material. The work itself was split up into goals, or definite steps to be accomplished, which goals varied with different children. Each child knew where he was going, the use of his material, and the particular goal on which he was working.

The next thing was to provide for a consciousness of increase of power by means of a pleasurable exercise of prowess and the measurement of it on the part of the child. To that end, tests were given. The tests were placed on a time basis, the children trying to see how many words they could recognize in three minutes, or how many arithmetic examples they could work correctly in that time. This roused a certain emotional excitement with a resultant increased discharge of energy. 
In some rooms arithmetic tests were given each day, and reading and phonics tests twice a week. These tests were not given on the old pass and fail basis, or to find out what the child did not know, but were designed to give the child full opportunity to measure himself; e.g., the children found keen interest in seeing how many words they could recognize in three minutes on a reading-test slip and in beating their own records.

About eighty children were in the experiment. They made good progress. Among them there are no discipline cases, so many of which are due to lack of adjustment to environment and to an attempt to fit the child to the curriculum rather than the curriculum to the child.

Some interesting cases arose at the beginning of the experiment. The following are two of them. They are typical, one of the slow child, the other of the quick, nervous type, both of whom furnish many of our ever-present discipline problems in the public schools.

S. G. was a slow, dreamy boy. When his class worked on a program basis, he fell steadily behind his fellows and became retarded in all his subjects. He grew discouraged, then became apathetic, and was finally apparently filled with a sense of inferiority and the idea that he could not undertake anything successfully. He was idle most of the time, and worried his different teachers greatly because they could not awaken any interest on his part.

When we started our experiment, S. G. was so diffident that he hated to have the other children see his work. In a board drawing lesson he was very self-conscious for he felt that his drawing was the worst, although that was not the case. He would ask what book he was going to have next in reading, and say he didn't want it. When the records of the tests were read he would shyly remark that he knew where he would stand, and his gloomy prognostication was unfortunately too of ten correct.

The teachers found that S. G. had no faith in his own powers. They therefore started to build that up, by arranging his work in short goals, easy of attainment and quickly accomplished. They soon succeeded in making him feel a growing sense of power. The tests also helped this. He, of course, took tests suited to his particular stage of development, and the good marks he obtained encouraged him. One day he took a test in arithmetic and got it correct. It was a pleasure to see how he expanded under the stimu- 
lus of repeated small successes. He is no longer retarded, and has conquered that excessive diffidence and lack of faith in himself.

V. G. is a very intelligent, quick, nervous child. Working on a program, she would be a continual problem. She is possessed of an overpowering curiosity, and knows where all her classmates are in their studies. She is continually trying to beat her own and other people's records. The free program gives her every opportunity to do this, and she has made splendid progress.

No teacher could hold V. G's. attention on the same reading page as children slower than herself, and no teacher could keep her sitting still. V. G. had been ill for some time. On her return, she found that while she was on the second story of the primer, all her friends were ahead. She quickly ascertained where they were, set herself to compete with one particular child, and soon covered the ground she had lost, and made up for lost time.

In this experiment we found, among other things, that we can only set the stage for the motivation of the child. We cannot supply the motives, for the child's motives are not those of the adult. In Days of Discovery Gordon Smith describes his childhood. There he has depicted some queer childish motives and has shown the great dividing gulf between the childish and the adult point of view. It is interesting to note that most of the motives he portrays arose out of a desire to dominate others, to dominate a given situation, and to experience the pleasure of exercising prowess.

To us the child's motives of ten appear odd and illogical. They are not characterized by prudence and foresight, but arise out of some present desire crying for immediate satisfaction.

One morning a boy worked one hundred and five examples in arithmetic and got one hundred and three of them correct. It turned out that the next arithmetic test that he was to take was so arranged that a child can correct his own examples. The boy was working to get this test and have what seemed to him the extreme pleasure of marking his own work, a thing he had never done before. Another little girl worked very hard on word lists. She even slept with them under her pillow, so her mother assured us. We found that at the same time she delighted in showing her father how many words she could pick out in the newspaper.

Often the source of motivation is in the joy in mere activity which is so strong in the child at this age. To illustrate: In one of the 
rooms in which this experiment was tried the children were of kindergarten age. Kindergarten materials were accessible in the room, but were only chosen once by two children, and then under the influence of suggestion from the teacher. Under different circumstances these children would be actively and interestedly engaged in kindergarten activities or in working with Montessori material, but instead they were all working at the usual primary subjects.

Does not the child go to school with the knowledge that he is going there to learn to read and write, etc., and does he not arrive ready to take what he finds there? It remains for the teacher to direct his energy and make the learning of reading, etc., feasible to each child. 